\title{
Kemampuan Mahasiswa Program Studi Pendidikan Matematika FKIP Universitas Mataram dalam Membuat RPP dengan Menerapkan Model Problem Based Learning
}

\author{
Yenny Indriani ${ }^{1 *}$, Sripatmi ${ }^{2}$, Arjudin $^{2}$, Sri Subarinah $^{2}$ \\ ${ }^{1}$ Mahasiswa Pendidikan Matematika, FKIP, Universitas Mataram, Mataram \\ 2 Pendidikan Matematika, FKIP, Universitas Mataram, Mataram \\ yennyindriani7@gmail.com
}

Diterima: 16-12-2021; Direvisi: 30-12-2021; Dipublikasi: 30-12-2021

\begin{abstract}
This study aims to determine the level of ability and describe the constraints of mathematics education students in making a learning implementation design with a problem based learning model. This type of research is descriptive exploratory with quantitative and qualitative approaches. The research population was all students in the 7th semester of the mathematics education study program, which were divided into 3 classes, namely classes A, B, and C. Sample of this study were 7 students who PLP courses. The results showed that there were 9 aspects of the learning implementation design assessment that would be assessed on 7 students. The average percentage of the 9 aspects assessed by researchers was $72.67 \%$ and those assessed by teachers were $73.67 \%$, both of which were in the good category.
\end{abstract}

Keywords: students ability; learning implementation plan; problem based learning

\begin{abstract}
Abstrak
Penelitian ini bertujuan untuk mengetahui tingkat kemampuan dan mendeskripsikan kendala mahasiswa program studi pendidikan matematika dalam membuat RPP dengan model problem based learning. Jenis penelitian ini adalah deskriptif eksploratif dengan pendekatan kuantitatif dan kualitatif. Populasi penelitian adalah seluruh mahasiswa PLP program studi pendidikan matematika semester 7 yang terbagi menjadi 3 kelas, yaitu kelas A, B, dan C. Sampel penelitian ini adalah 7 orang mahasiswa PLP yang menyusun RPP model problem based learning. Hasil penelitian menunjukkan bahwa ada 9 aspek penilaian RPP yang akan dinilai pada 7 mahasiswa yang membuat RPP model problem based learning. Rata-rata persentase dari ke 9 aspek yang dinilai peneliti sebanyak $72,67 \%$ dan yang dinilai guru sebanyak $73,67 \%$, keduanya berada pada kategori baik.
\end{abstract}

Kata Kunci: kemampuan mahasiswa; RPP; problem based learning

\section{PENDAHULUAN}

Sekolah merupakan salah satu pendidikan formal yang diwajibkan untuk seluruh anak bangsa Indonesia. Proses pendidikan meliputi unsur pendidik dan peserta didik. Pendidikan di sekolah dilakukan melalui proses pembelajaran di kelas. Dalam proses pembelajaran ada tujuan-tujuan yang harus dicapai. Tujuan pembelajaran bisa tercapai dengan baik bila proses pembelajaran direncanakan dengan baik pula. Rencana yang dibuat pendidik untuk melaksanakan proses kegiatan pembelajaran di kelas dituangkan dalam bentuk (RPP) Rencana Pelaksanaan Pembelajaran (Izzati, 2017). 
Guru berperan penting dalam mendidik siswa di sekolah. Sebagai tenaga pendidik peran guru mengajarkan berbagai pelajaran, memberi nasehat agar siswa memiliki kepribadian baik sesuai karakter bangsa (Putri \& Agustyaningrum, 2017). Kemampuan guru mengelola kelas dan menyiapkan skenario pembelajaran adalah salah satu unsur utama sebelum memasuki kelas. Kemampuan dan kemahiran menyusun rencana pembelajaran yang akan disampaikan kepada siswa membantu tercapai secara optimal tujuan dari pembelajaran yang diharapkan.

Guru yang lebih siap untuk memasuki ruangan kelas berdampak terhadap siswa. Baik dari prestasi siswa, motivasi dan kepahaman siswa terhadap materi pelajaran yang disampaikan guru tersebut. Guru yang memiliki kemampuan menguasai kelas dan materi ajar akan berdampak terhadap motivasi belajar siswa. Hal ini sebagaimana Nurmahmidah (2017:140) mengatakan bahwa penting dan perlu diketahui oleh setiap guru dalam peranannya yaitu dapat menumbuhkan gairah, merasa senang dan semangat belajar bagi siswa. Menurut Winkel (Winkel, 2004:169), motivasi belajar adalah keseluruhan daya penggerak psikis dalam diri siswa yang menimbulkan kegiatan belajar, menjamin kelangsungan kegiatan belajar itu demi mencapai suatu tujuan.

Salah satu kampus yang mencetak calon guru yang smart dan inovatif adalah Fakultas Keguruan dan Ilmu Pendidikan (FKIP) Universitas Mataram. Mahasiswa program studi pendidikan matematika harus mampu memiliki kemampuan yang baik dalam menyusun perangkat pembelajaran termasuk RPP untuk diaplikasikan pada saat mereka mengajar di kelas. Mata kuliah P3M (Pengembangan Program Pembelajaran Matematika) menjadi salah satu dasar pengembangan kemampuan penyusunan RPP. Dalam mata kuliah ini diajarkan cara menyusun RPP yang baik, mulai dari menganalisa kemampuan awal peserta didik, menentukan alokasi waktu, menentukan indikator, media, bahan ajar sampai membuat instrumen yang tepat untuk mengukur ketercapaian tujuan pembelajaran. RPP yang di bahas dalam mata kuliah Pengembangan Program Pembelajaran Matematika (P3M) adalah RPP untuk sekolah menengah pertama dan sekolah menengah atas. Melalui penyusunan RPP ini mahasiswa mampu menyusun berbagai tahap-tahap pembelajaran inovatif yang diterapkan pada saat pembelajaran berlangsung.

Tujuan dari mata kuliah Pengembangan Program Pembelajaran Matematika adalah membekali mahasiswa calon guru mempunyai kemampuan menyusun RPP sebaik mungkin agar proses kegiatan belajar dan mengajar di kelas berhasil. RPP merupakan skenario pembelajaran yang wajib bagi para pendidik untuk disusun secara matang agar pembelajaran berjalan baik dan tujuan dari pembelajaran dapat tercapai sesuai harapan. Berbekal mata kuliah tersebut, mahasiswa akan lebih memiliki kemampuan mengajar yang lebih baik.

Salah satu model pembelajaran yang dapat meningkatkan kemampuan pemahaman dan pemecahan masalah pada pembelajaran matematika adalah Problem Based Learning (PBL). PBL merupakan model pembelajaran yang berorientasi pada kerangka kerja 
teoritik konstruktivisme. Dalam model PBL, fokus pembelajaran ada pada masalah yang dipilih sehingga pebelajar tidak sama mempelajari konsep-konsep yang berhubungan dengan masalah tetapi juga metode ilmiah untuk memecahkan masalah tersebut. Oleh sebab itu, pebelajar tidak saja harus memahami konsep yang relevan dengan masalah yang menjadi pusat perhatian tetapi juga memperoleh pengalaman belajar yang berhubungan dengan keterampilan menerapkan metode ilmiah dalam pemecahan masalah dan menumbuhkan pola berpikir kritis (Ngalimun, 2014:90-91).

Bila pembelajaran yang dimulai dengan suatu masalah, apalagi kalau masalah tersebut bersifat kontekstual, maka dapat terjadi ketidakseimbangan kognitif pada diri pebelajar. Keadaan ini dapat mendorong rasa ingin tahu sehingga memunculkan bermacam-macam pertanyaan disekitar masalah. Bila pertanyaan-pertanyaan telah muncul dalam diri pebelajar maka motivasi intrinsik mereka untuk belajar akan tumbuh. Pada kondisi tersebut diperlukan peran guru sebagai fasilitator untuk mengarahkan pebelajar tentang "konsep apa yang harus dilakukan", "apa yang harus dilakukan" atau "bagaimana melakukannya" dan seterusnya. Dari paparan tersebut dapat diketahui bahwa penerapan PBL dalam pembelajaran dapat mendorong siswa/mahasiswa mempunyai inisiatif untuk belajar secara mandiri.

Model ini juga sesuai untuk diterapkan pada mata kuliah Pengembangan Program Pembelajaran Matematika, karena mahasiswa diminta untuk menyusun RPP dan mereka mempraktekan RPP tersebut ke sekolah tempat PLP. Setiap pertemuan perkuliahan, mahasiswa ditugaskan untuk berlatih membuat RPP kemudian pada saat perkuliahan, mereka di intruksikan untuk mencoba mempraktekan di kelas secara berkelompok. Untuk kelompok yang sudah bagus RPPnya, mereka ditugaskan ke sekolah formal untuk praktek secara langsung dihadapan siswa. Hal ini salah satu bentuk latihan mahasiswa agar terbiasa dan terlatih mengajar sesuai dengan RPP yang mereka susun sebelumnya.

Sesuai dengan yang peneliti dapatkan, maka terdapat permasalahan yang ditemukan termasuk dengan keberadaan RPP Model PBL, yaitu mahasiswa kesulitan dalam mengaplikasikan RPP dan melakukan penilaian pada siswa. Selama proses pembelajaran berlangsung, penggunaan waktu dan teknik penguasaan kelas merupakan tugas yang cukup sulit. Dalam penggunaan waktu di kelas, terkadang waktu siswa untuk mempraktekkan apa yang dipelajari kurang, sehingga mereka hanya mendapatkan secara teori namun kurang dalam mempraktekkannya. Sedangkan untuk teknik penguasaan kelas, tidak semua siswa mampu mengikuti pelajaran dengan baik, meskipun guru sudah mengawasi mereka di depan dan di belakang kelas.

Berdasarkan uraian tersebut, maka peneliti bermaksud untuk menganalisis kemampuan mahasiswa Program Studi Pendidikan Matematika FKIP Universitas Mataram dalam menyusun dan melaksanakan RPP model Problem Based Learning pada mata kuliah PLP (Pengenalan Lapangan Persekolahan) Tahun 2020/2021 agar diperoleh data yang 
valid dan komprehensif. Kajian ini juga diharapkan dapat dijadikan acuan untuk mengambil kebijakan dan bahan evaluasi pada pelaksanaan ke depannya.

\section{METODE PENELITIAN}

Jenis penelitian yang digunakan dalam penelitian ini adalah deskriptif eksploratif dengan pendekatan kuantitatif dan kualitatif. Peneliti mengambil penelitian deskriptif eksploratif karena terdapat 2 tujuan penelitian yaitu untuk mengetahui tingkat kemampuan mahasiswa dalam membuat RPP model Problem Based Learning dengan pendekatan kuantitatif dan mendeskripsikan kendala mahasiswa dalam membuat RPP model Problem Based Learning dengan pendekatan kualitatif (Arikunto, 2013).

Populasi dalam penelitian ini adalah seluruh mahasiswa PLP program studi pendidikan matematika semester 7 FKIP Universitas Mataram 2020/2021, yang terbagi menjadi 3 kelas, yaitu kelas A, B, dan C. Adapun rinciannya sebagai berikut:

Tabel 1. Jumlah Mahasiswa PLP Program Studi Pendidikan Matematika Semester 7

\begin{tabular}{cc}
\hline Kelas & Banyak Mahasiswa \\
\hline A & 20 \\
\hline B & 27 \\
\hline C & 23 \\
\hline Jumlah & 70 \\
\hline
\end{tabular}

Sampel yang digunakan dalam penelitian ini sebanyak 7 orang mahasiswa Program Studi Pendidikan Matematika Fakultas Keguruan dan Ilmu Pendidikan Universitas Mataram tahun ajaran 2020/2021 yang membuat RPP Model Probem Based Learning dalam kegiatan PLP. Adapun tabel rekaptulasi model yang dikembangkan mahasiswa program studi pendidikan matematika di RPP, yaitu sebagai berikut:

Tabel 2. Rekaptulasi model RPP yang dikembangkan mahasiswa

\begin{tabular}{ccc}
\hline No & Model RPP Yang Dikembangkan & Banyak Mahasiswa \\
\hline 1. & Model Problem Based Learning & 7 \\
\hline 2. & STAD & 4 \\
\hline 3. & Discovery Learning & 25 \\
\hline 4. & Kooperatif Learning & 18 \\
\hline 5. & Pembelajaran Langsung & 14 \\
\hline 6. & Inquiri & 1 \\
\hline 7. & Think, pair and share & 1 \\
\hline \multicolumn{2}{c}{ Total } \\
\hline
\end{tabular}

Instrumen yang digunakan dalam penelitian ini, yaitu pedoman wawancara dan lembar penilaian RPP. Pada pedoman wawancara terdapat 12 pertanyaan yang harus dijawab oleh mahasiswa sampel penelitian. Pedoman wawancara dalam penelitian ini menggunakan pedoman wawancara yang terstruktur. Pada pedoman wawancara terdapat 12 pertanyaan yang harus dijawab oleh mahasiswa sampel penelitian. Pedoman wawancara dalam penelitian ini menggunakan pedoman wawancara yang terstruktur. Bagian ini harus memaparkan metode pelaksanaan, desain pelaksanaan, prosedur 
pelaksanaan yang digunakan dalam penelitian. Dilengkapi dengan pemaparan tempat penelitian secara umum, dan subjek penelitian dengan rinci.

Tabel 3. Kisi-kisi Pedoman Wawancara

\begin{tabular}{|c|c|}
\hline Komponen & Sub Komponen \\
\hline $\begin{array}{l}\text { Informasi awal tentang } \\
\text { RPP matematika }\end{array}$ & Pernahkan membuat RPP \\
\hline \multirow{4}{*}{$\begin{array}{l}\text { Komponen apa saja yang } \\
\text { harus ada } \\
\text { penyusunan RPP }\end{array}$} & Merumuskan indikator \\
\hline & Merumuskan tujuan pembelajaran \\
\hline & $\begin{array}{llll}\begin{array}{l}\text { Pembagian materi } \\
\text { pertemuan }\end{array} & \text { pada setiap } \\
\end{array}$ \\
\hline & $\begin{array}{l}\text { Menentukan metode dan model } \\
\text { pembelajaran yang digunakan dalam } \\
\text { menyusun RPP }\end{array}$ \\
\hline \multirow{5}{*}{$\begin{array}{lr}\text { Rencana } & \text { Pelaksanaan } \\
\text { Pembelajaran } & \text { model } \\
\text { Problem Based Learning }\end{array}$} & Pengetahuan tentang RPP Problem \\
\hline & \\
\hline & $\begin{array}{l}\text { Langkah-langkah yang dilakukan } \\
\text { dalam penyusunan kegiatan RPP } \\
\text { Problem Based Learning }\end{array}$ \\
\hline & Sumber belajar yang digunakan \\
\hline & in belajar \\
\hline \multirow[t]{2}{*}{ Kesulitan yang dialami } & $\begin{array}{lcc}\text { Kesulitan } & \text { dalam } & \text { memilih } \\
\text { model/metode pembelajaran } & \end{array}$ \\
\hline & $\begin{array}{l}\text { Kesulitan dalam membuat RPP model } \\
\text { Problem Based Learning }\end{array}$ \\
\hline $\begin{array}{l}\text { Pendapat tentang Problem } \\
\text { Based Learning }\end{array}$ & $\begin{array}{l}\text { Pengetahuan tentang Problem Based } \\
\text { Learning yang dilaksanakan di kelas }\end{array}$ \\
\hline
\end{tabular}

Instrumen penilaian RPP digunakan untuk mengetahui kemampuan mahasiswa dalam membuat RPP yang dikembangkannya. Bentuk lembar penilaian yang digunakan adalah angket berstruktur. Angket berstruktur digunakan untuk mendapatkan hasil dari penilaian mahasiswa dalam membuat RPP. Angket berstruktur ini menggunakan skala likert dengan skala 5, 4, 3, 2 dan 1 yang terdiri dari sangat baik, baik, cukup, kurang, dan sangat kurang. Dalam penelitian ini, kisi-kisi yang digunakan pada lembar penilaian RPP meliputi: aspek identitas mata pelajaran, rumusan indikator, rumusan tujuan pembelajaran, materi pembelajaran, sumber belajar, media belajar, metode pembelajaran, langkah-langkah pembelajaran dengan menerapkan model Problem Based Learning, dan penilaian belajar.Alur langkah penelitian harus disajikan dalam bagian ini lengkap dengan keterangan. Keterangan gambar yang ditempatkan sebagai bagian dari judul gambar (keterangan gambar) bukan bagian dari gambar.

Tabel 4. Kisi-kisi Lembar Penilaian RPP Model Problem Based Learning

\begin{tabular}{clll}
\hline Aspek yang diamati & \multicolumn{3}{c}{ Indikator Penilaian } \\
\hline $\begin{array}{c}\text { Identitas mata } \\
\text { pelajaran }\end{array}$ & \multicolumn{1}{c}{ Kejelasan identitas } \\
\cline { 2 - 4 } Perumusan indikator & $\begin{array}{l}\text { Kelengkapan identitas } \\
\text { indikator penjabaran kompetensi dasar dalam }\end{array}$ \\
\hline & Kesesuaian dengan indikator & \\
\hline
\end{tabular}




\begin{tabular}{|c|c|}
\hline Aspek yang diamati & Indikator Penilaian \\
\hline $\begin{array}{l}\text { Perumusan Tujuan } \\
\text { Pembelajaran }\end{array}$ & $\begin{array}{l}\text { Kesesuaian dengan aspek Audience, Behaviour, } \\
\text { Condition, dan Degree }\end{array}$ \\
\hline \multirow{3}{*}{ Materi pembelajaran } & Kelengkapan materi ajar \\
\hline & Keruntutan materi ajar \\
\hline & Kesesuaian dengan kebutuhan siswa \\
\hline \multirow[t]{2}{*}{ Sumber belajar } & Kesesuaian sumber belajar tujuan pembelajaran \\
\hline & $\begin{array}{l}\text { Kesesuaian sumber belajar dengan pendekatan } \\
\text { pembelajaran }\end{array}$ \\
\hline Media belajar & $\begin{array}{l}\text { Media yang dipilih sesuai dengan tujuan } \\
\text { pembelajaran, materi pembelajaran, kondisi kelas, } \\
\text { kebutuhan siswa, dan memperhatikan keselamatan } \\
\text { siswa. }\end{array}$ \\
\hline \multirow[t]{2}{*}{ Metode pembelajaran } & $\begin{array}{l}\text { Kesesuaian pendekatan dan model pembelajaran } \\
\text { dengan tujuan pembelajaran }\end{array}$ \\
\hline & $\begin{array}{l}\text { Kesesuaian pendekatan dan model pembelajaran } \\
\text { dengan materi ajar }\end{array}$ \\
\hline \multirow{2}{*}{$\begin{array}{l}\text { Langkah-langkah } \\
\text { pembelajaran dengan } \\
\text { model Problem Based } \\
\text { Learning }\end{array}$} & $\begin{array}{l}\text { Menampilkan kegiatan pendahuluan, inti, dan } \\
\text { penutup dengan jelas sesuai dengan sintaks } \mathrm{PBL} \\
\text { dari tahapan fase } 1 \text { sampai dengan fase } 5 \text {. }\end{array}$ \\
\hline & Alokasi waktu pembelajaran \\
\hline \multirow[t]{2}{*}{ Penilaian belajar } & Kesesuaian teknik penilaian \\
\hline & Kelengkapan instrument \\
\hline
\end{tabular}

Analisis statistik deskriptif digunakan untuk menganalisis hasil penilaian RPP dengan mengetahui tingkat kemampuan mahasiswa program studi pendidikan matematika universitas mataram dalam membuat RPP model Problem Based Learning. Data hasil penilaian RPP model Problem Based Learning akan dianalisis dengan menjumlahkan skor kemudian menghitung dalam bentuk persentase. Pedoman penskoran hasil penilaian lembar RPP model Problem Based Learning didasarkan pada indikator penilaian RPP model Problem Based Learning yang telah diuraikan pada lampiran 1. Analisis hasil penilaian lembar RPP model Problem Based Learning dilakukan dengan cara sebagai berikut.

1). Menghitung skor pada setiap butir penilaian RPP model Problem Based Learning dengan menggunakan rumus sebagai berikut.

\section{Keterangan:}

$$
\text { Persentase }=\frac{\text { Jumlah Skor }}{\text { Skor Maksimum }} \times 100 \%
$$

$$
\begin{aligned}
& \text { Jumlah Skor = skor didapat dari butir penilaian } \\
& \text { Skor Maksimum = jumlah skor tertinggi dikali dengan jumlah butir penilaian }
\end{aligned}
$$

2). Setelah mendapatkan skor hasil dari lembar penilaian RPP model Problem Based Learning, dilakukan pemberian kategori skor untuk mengetahui tingkat kemampuan mahasiswa dalam membuat RPP model PBL. Kategori skor penilaian RPP model Problem Based Learning adalah pengkategorian dengan skala lima pada tabel berikut (Arikunto, 2013). 
Tabel 5. Kategori Kemampuan Membuat RPP model Problem Based Learning Persentase Hasil Peneltitian Kemampuan RPP Model Problem Based Learning Kategori

\begin{tabular}{cc}
\hline $80-100$ & Sangat Baik \\
\hline $60-79$ & Baik \\
\hline $40-59$ & Cukup \\
\hline $10-39$ & Kurang \\
\hline $0-9$ & Sangat Kurang \\
\hline
\end{tabular}

(Widoyoko, 2009: 238).

\section{HASIL DAN PEMBAHASAN}

Pengambilan data dilakukan pada tanggal 20 November sampai dengan 20 Desember 2020 untuk mengetahui tingkat kemampuan mahasiswa program studi pendidikan matematika FKIP Universitas Mataram dalam membuat RPP dengan menerapkan model Problem Based Learning dan mendeskripsikan kendala mahasiswa program studi pendidikan matematika FKIP Universitas Mataram dalam membuat RPP dengan menerapkan model Problem Based Learning. Populasi dalam penelitian ini yaitu seluruh mahasiswa semester 7 program studi pendidikan matematika FKIP Universitas Mataram yang melaksanakan program PLP dengan jumlah 70 orang mahasiswa.

Dari 70 orang mahasiswa tersebut, terdapat 7 orang mahasiswa yang membuat RPP model Problem Based Learning dan 63 orang mahasiswa yang membuat RPP bukan Problem Based Learning. Penelitian ini dilakukan di FKIP Universitas Mataram.

\subsection{Penilaian RPP}

Data kategori hasil penilaian RPP model Problem Based Learning terhadap mahasiswa sampel penelitian yang dinilai oleh peneliti dan guru. Data hasil kategori tingkat kemampuan mahasiswa dalam membuat RPP model Problem Based Learning yang dinilai oleh peneliti dapat dilihat pada Gambar 1 berikut ini:

Gambar 1. Hasil Kategori Tingkat Kemampuan Mahasiswa dalam Membuat RPP Model Problem Based Learning yang Dinilai Peneliti

\begin{tabular}{|c|c|c|c|c|c|c|c|c|c|c|c|c|c|c|c|c|c|}
\hline \multirow{2}{*}{ No } & \multirow{2}{*}{ Sampel } & \multicolumn{2}{|c|}{ So1 } & \multicolumn{2}{|c|}{502} & \multicolumn{2}{|c|}{ S03 } & \multicolumn{2}{|c|}{ So4 } & \multicolumn{2}{|c|}{ Sos } & \multicolumn{2}{|c|}{ S06 } & \multicolumn{2}{|c|}{ S07 } & \multirow[b]{2}{*}{ Persentase } & \multirow[b]{2}{*}{ Kategori } \\
\hline & & Skor & Ktg & Skor & Ktg & Skor & Keg & Skor & Ktg & Skor & Ktg & Skor & Ktg & Skor & Ktg & & \\
\hline 1. & $\begin{array}{l}\text { Identitas mata } \\
\text { pelajaran }\end{array}$ & so & SB & so & SB & 34 & B & 41 & SB & 41 & SB & 41 & SB & 47 & SB & $86,84 \%$ & $\mathrm{SB}$ \\
\hline 2. & $\begin{array}{l}\text { Perumusan } \\
\text { indikator }\end{array}$ & 17 & SB & 19 & SB & 4 & $\bar{K}$ & 8 & C & 8 & $\mathrm{~K}$ & 8 & C & 20 & SB & $60 \%$ & B \\
\hline 3. & $\begin{array}{l}\text { Perumusan } \\
\text { tujuan } \\
\text { pembelajaran }\end{array}$ & 40 & SB & 39 & SB & 8 & $\mathrm{~K}$ & 31 & B & 27 & $\mathbf{B}$ & 36 & SB & 32 & SB & $76,05 \%$ & B \\
\hline 4. & $\begin{array}{l}\text { Materi } \\
\text { pembelajaran }\end{array}$ & 4 & $\mathrm{~K}$ & 16 & B & 13 & B & 8 & $\mathbf{C}$ & 17 & SB & 20 & SB & 16 & SB & $67,1 \%$ & B \\
\hline 5. & Sumber belajar & 12 & B & 17 & SB & 16 & SB & 8 & C & 16 & SB & 12 & B & 17 & SB & $70 \%$ & B \\
\hline 6. & Media belajar & 16 & SB & 18 & SB & 17 & SB & 8 & C & 16 & SB & 16 & SB & 16 & SB & $76,42 \%$ & B \\
\hline 7. & $\begin{array}{l}\text { Metode } \\
\text { pembelajaran }\end{array}$ & 24 & SB & 20 & SB & 25 & SB & 20 & SB & 20 & SB & 20 & SB & 25 & SB & $88 \%$ & SB \\
\hline 8. & $\begin{array}{l}\text { Langkah- } \\
\text { langkah } \\
\text { pembelajaran } \\
\text { dengan model } \\
\text { Problem Based } \\
\text { Learning }\end{array}$ & 35 & SB & 27 & $\mathbf{B}$ & 20 & C & 20 & C & 31 & SB & 33 & SB & 35 & SB & $82,02 \%$ & SB \\
\hline 9. & $\begin{array}{l}\text { Penilaian } \\
\text { belajar }\end{array}$ & 5 & $\mathrm{~K}$ & 8 & C & 7 & C & 7 & C & 12 & B & 15 & B & 15 & B & $43,3 \%$ & $\mathbf{C}$ \\
\hline & Total skor & 203 & SB & 214 & SB & 144 & C & 151 & B & 188 & B & 201 & SB & 223 & SB & $72,67 \%$ & B \\
\hline
\end{tabular}


Berdasarkan pemaparan gambar di atas, data hasil penelitian menunjukkan bahwa mahasiswa program studi pendidikan matematika FKIP Universitas Mataram mampu membuat RPP model Problem Based Learning. Adapun rata-rata persentase hasil penilaian RPP model Problem Based Learning terhadap mahasiswa sampel penelitian yang dinilai oleh peneliti adalah sebanyak 72,67\%, dengan kategori baik.

Data kategori hasil penilaian RPP model Problem Based Learning terhadap mahasiswa sampel penelitian yang dinilai oleh guru dapat dilihat pada Gambar 2 berikut ini:

Gambar 2. Hasil Kategori Tingkat Kemampuan Mahasiswa dalam Membuat RPP Model Problem Based Learning yang Dinilai Guru

\begin{tabular}{|c|c|c|c|c|c|c|c|c|c|c|c|c|c|c|c|c|c|}
\hline \multirow{2}{*}{ No } & \multirow{2}{*}{$\begin{array}{l}\text { Sampel } \\
\text { Asper } \\
\text { yang dinting }\end{array}$} & \multicolumn{2}{|c|}{ So1 } & \multicolumn{2}{|c|}{ SO2 } & \multicolumn{2}{|c|}{ S03 } & \multicolumn{2}{|c|}{ S04 } & \multicolumn{2}{|c|}{505} & \multicolumn{2}{|c|}{ SoG } & \multicolumn{2}{|c|}{ So7 } & \multirow{2}{*}{ Persentase } & \multirow{2}{*}{ Kategori } \\
\hline & & Skor & Ktg & Skor & Ktg & Skor & Ktg & Slcor & Ktg & Skor & Ktg & Skor & Ktg & Skor & Ktg & & \\
\hline 1. & $\begin{array}{l}\text { Identitas mata } \\
\text { pelajaran }\end{array}$ & 50 & SB & 50 & SB & 32 & $\mathbf{B}$ & 41 & SB & 38 & B & 41 & SB & 46 & SB & $87,14 \%$ & SB \\
\hline 2. & $\begin{array}{l}\text { Perumusan } \\
\text { indikator }\end{array}$ & 19 & SB & 20 & SB & 4 & $\mathbf{K}$ & 10 & C & 8 & C & 9 & C & 20 & SB & $64,25 \%$ & $\mathbf{B}$ \\
\hline 3. & $\begin{array}{l}\text { Perumusan } \\
\text { tujuan } \\
\text { pembelajaran }\end{array}$ & 39 & SB & 40 & SB & 8 & $\mathrm{~K}$ & 36 & SB & 27 & B & 36 & SB & 32 & SB & $77,85 \%$ & $\mathrm{SB}$ \\
\hline 4. & $\begin{array}{l}\text { Materi } \\
\text { pembelajaran }\end{array}$ & 4 & $\bar{K}$ & 15 & B & 16 & SB & 12 & B & 17 & SB & 20 & SB & 17 & SB & $72,15 \%$ & B \\
\hline 5. & Sumber belajar & 14 & $\overline{\mathbf{B}}$ & 18 & SB & 18 & SB & 12 & B & 16 & SB & 14 & $\overline{\mathbf{B}}$ & 18 & SB & $79 \%$ & B \\
\hline 6. & Media belajar & 17 & SB & 20 & SB & 16 & SB & 10 & C & 17 & SB & 16 & SB & 16 & SB & $80 \%$ & $\mathrm{SB}$ \\
\hline 7. & $\begin{array}{l}\text { Metade } \\
\text { pembelajaran }\end{array}$ & 24 & SB & 21 & SB & 25 & SB & 20 & SB & 16 & $\mathbf{B}$ & 20 & SB & 25 & SB & $86,28 \%$ & SB \\
\hline 8. & $\begin{array}{l}\text { Langkah- } \\
\text { langkah } \\
\text { pembelajaran } \\
\text { dengan model } \\
\text { Problem Based } \\
\text { Learming } \\
\end{array}$ & 35 & SB & 30 & SB & 25 & B & 20 & C & 33 & $\overline{S B}$ & 33 & SB & 35 & SB & $86,11 \%$ & SB \\
\hline 9. & $\begin{array}{l}\text { Penilaian } \\
\text { belajar }\end{array}$ & 3 & $\mathbf{K}$ & 8 & C & 5 & C & 7 & C & 12 & SB & 15 & $\mathbf{B}$ & 15 & B & $62 \%$ & $\mathbf{B}$ \\
\hline & Total skor & 205 & SB & 222 & SB & 149 & $\mathbf{B}$ & 168 & $\mathbf{B}$ & 184 & $\mathbf{B}$ & 206 & SB & 224 & SB & 73.67 & B \\
\hline
\end{tabular}

Berdasarkan pemaparan gambar di atas, rata-rata persentase hasil penilaian RPP model Problem Based Learning terhadap mahasiswa sampel penelitian yang dinilai oleh guru yaitu sebanyak 73,67\%, dengan kategori baik.

\subsection{Wawancara}

Hasil wawancara pada mahasiswa program studi pendidikan matematika FKIP Universitas Mataram yang membuat RPP model Problem Based Learning, dapat disimpulkan bahwa rata-rata mahasiswa yang menjadi sampel penelitian masih kesulitan dalam mengaplikasikan langkah-langkah pembelajaran model Problem Based Learning, kesulitan melakukan tindakan atau mengaplikasikan RPP di kelas, dan pemilihan masalah kontekstual yang akan dipelajari.

Data kesalahan penyusunan RPP berdasarkan temuan peneliti dan guru adalah sebagai berikut. Pertama, ada 4 mahasiswa yang melakukan kesalahan penulisan pada aspek identitas mata pelajaran. Kesalahan tersebut meliputi (1) tidak mencantumkan satuan pendidikan, (2) tidak mencantumkan alokasi waktu pembelajaran, (3) tidak mencantumkan kompetensi inti (4) tidak mencantumkan kompetensi dasar (5) tidak mencantumkan indikator (6) tujuan pembelajaran tidak dicantumkan.

Kesalahan format yang kedua adalah kesalahan perumusan indikator. Ada 4 mahasiswa yang melakukan kesalahan, bahkan ada beberapa yang tidak mencantumkan perumusan 
indikator. Kesalahan pada perumusan indikator yang dimaksud antara lain: (1) tidak dapat merumuskan indikator secara tepat, (2) tidak menggunakan kata operasional yang tepat sesuai tuntutan dalam kompetensi dasar, dan (3) indikator tidak terstruktur dengan jelas.

Kesalahan format yang ketiga adalah kesalahan perumusan tujuan pembelajaran. Perumusan tujuan pembelajaran yang dimaksud antara lain kesesuaian tujuan pembelajaran dengan indikator dan kesesuaian dengan aspek audience, behavior, condition, dan degree. Ada 3 mahasiswa yang melakukan kesalahan pada perumusan tujuan pembelajaran yaitu perumusan tujuan pembelajaran tidak sesuai dengan kompetensi dasar, unsur indikator seperti audience, behavior, condition, dan degree tidak lengkap, dan bahkan ada 1 mahasiswa yang tidak mencantumkan perumusan tujuan pembelajaran.

Kesalahan format yang keempat adalah kesalahan materi pembelajaran. Terkait dengan penyusunan materi pembelajaran, ada 3 mahasiswa yang melakukan kesalahan. Kesalahan ini terjadi disebabkan oleh materi tidak lengkap. Materi yang menuntut penguasaan konseptual seperti definisi dan ciri-ciri tertentu tidak dicantumkan. Begitu pula dengan materi yang bersifat procedural. Materi yang berkaitan dengan langkahlangkah penyusunan teks banyak yang tidak dicantumkan secara lengkap.

Selanjutnya, format yang kelima adalah sumber belajar. Ada 2 mahasiswa yang melakukan kesalahan dalam penyusunan pada bagian sumber belajar diantaranya mahasiswa yang membuat RPP tidak mencantumkan asal sumber yang dipergunakan secara jelas, baik segi pengarang dan penerbitannya. Penyusunan daftar pustaka pun belum sesuai aturan. Alat pembelajaran hanya disampaikan secara singkat dan tidak spesifik. Misalnya, teks hikayat yang tidak sampaikan judul teks dan pengarangnya.

Kesalahan format yang keenam adalah mediar belajar. Ada 2 mahasiswa yang melakukan kesalahan dalam penyusunan pada bagian media belajar. Diantaranya mahasiswa yang membuat RPP tidak menyesuaikan dengan tujuan pembelajaran, materi pembelajaran, dan pendekatan saintifik. Media belajar yang digunakan tidak sesuai dengan kondisi kelas dan kebutuhan siswa.

Terkait dengan metode pembelajaran, dari hasil penelitian tidak ada mahasiswa yang melakukan kesalahan. Semua sampel mampu membuat metode pembelajaran dengan baik. Metode pembelajaran yang dibuat sesuai dengan pendekatan pembelajaran, model pembelajaran, materi ajar, dan tujuan pembelajaran. Jadi, tidak ditemukan kesalahan dalam membuat metode pembelajaran pada seluruh sampel penelitian.

Selanjutnya pada langkah-langkah pembelajaran model Problem Based Learning. Ada 2 mahasiswa yang melakukan kesalahan pada rangkaian langkah-langkah pembelajaran, yang terbagi menjadi 3 tahap yaitu pendahuluan, isi, dan penutup. Rincian alokasi waktu dalam setiap rangkaian kegiatan pembelajaran terjadi pula. Dampaknya, alokasi waktu 
kegiatan penutup dan pembuka terkesan dicantumkan seadanya tanpa ada dasar yang jelas padahal kegiatan pembuka dan penutup memiliki peran penting dalam membangun motivasi belajar dan pengukur ketercapaian tujuan pembelajaran. Selain masalah saintifik yang belum tercermin dalam rangkaian kegiatan dan penentuan alokasi waktu yang tidak mendasar, pemahaman konsep saintifik belumlah sempurna. Saintifik dalam hal ini hanya dipandang sebagai sintak yang tidak perlu dicantumkan tanpa perlu ada tindak lanjut. Hal itu berdampak pada bagian rincian pembelajaran baik bagian pendahuluan, bagian inti, dan bagian penutup.

Pada bagian pendahuluan, penyusun RPP secara umum melakukan kesalahan dalam penentuan alokasi waktu yang berpengaruh pada ketidakjelasan bagian pembuka khususnya bagian apersepsi materi sebelumnya. Alokasi waktu dicantumkan, misalnya 10 menit tanpa mampu memberikan gambaran bagaimana pelaksanaan alokasi 10 menit untuk setiap rincian pembelajaran, bahkan beberapa RPP tidak mencantumkan bagian yang mengorientasikan siswa pada masalah atau yang mengarahkan ke RPP model Problem Based Learning. Pada bagian kegiatan inti pembelajaran yang memiliki peran esensial penentu ketercapaian tujuan pembelajaran, namun ada RPP yang belum mampu memenuhi tahapan/sintak yang digunakan pada model Problem Based Learning seperti mengembangkan hasil karya siswa. Pada kegiatan penutup terdapat kesalahan dalam penyusunannya. Kesalahan tersebut adalah RPP tidak mencantumkan bentuk kegiatan penutup yang seharusnya, misalnya seperti tindak lanjut, penyimpulan materi, ataupun refleksi. Kegiatan penutup dalam membuat RPP seharusnya dilakukan untuk mengakhiri aktifitas pembelajaran yang dapat dilakukan dalam bentuk rangkuman atau kesimpulan, penilaian dan refleksi, umpan balik, dan tindak lanjut.

Untuk penilaian belajar, ada 4 mahasiswa yang melakukan kesalahan pada bagian penilaian. Kesalahan pada penilaian meliputi (1) penentuan nilai akhir yang tidak jelas, (2) penilaian untuk ranah keterampilan atau psikomotor tidak ada, (3) penilaian tidak spesifik dan tidak sesuai dengan rumusan tujuan pembelajaran, (4) penskoran tidak dicantumkan dan rubrik penilaian tidak jelas, dan (5) petunjuk pengerjaan instrumen soal (6) penilaian belum lengkap karena hanya ada soal saja tanpa diikuti dengan cara dan pedoman penskoran untuk setiap soal. Dengan demikian, perlu pemaparan khusus dalam perkulihan untuk menghindari kurang lengkapnya prosedur penelitian yang disusun para calon guru tersebut.

Berdasarkan data yang diperoleh dari penilaian RPP terhadap mahasiswa sampel penelitian yang dinilai oleh peneliti dan guru, yaitu mahasiswa program studi pendidikan matematika FKIP Universitas Mataram yang membuat RPP model Problem Based Learning, ada beberapa mahasiswa yag masih belum memahami komponenkomponen RPP, terfokus pada identitas mata pelajaran yang tidak lengkap, materi pembelajaran yang tidak dicantumkan, sumber belajar yang tidak jelas, dan penilaian belajar yang tidak lengkap. Ini menunjukkan bahwa masih terdapat kekurangan pada penguasaan dan keterampilan mahasiswa dalam membuat RPP. Adapun data yang diperoleh pada hasil wawancara, terdapat beberapa kesulitan yang didapat oleh sampel 
dalam membuat RPP model Problem Based Learning yaitu mahasiswa kesulitan mengaplikasikan langkah-langkah pada RPP di kelas, kesulitan mencocokkan model pembelajaran dengan siswa, mengatur waktu yang telah disediakan dan pemilihan masalah kontekstual yang akan dipelajari.

\section{SIMPULAN}

Berdasarkan hasil analisis data dan pembahasan dapat disimpulkan bahwa:

1). Tingkat kemampuan mahasiswa program studi pendidikan matematika FKIP Universitas Mataram dalam membuat RPP yang menerapkan model Problem Based Learning berada pada kategori baik yaitu dengan rata-rata hasil penilaian dari peneliti dan guru adalah 73,13\%.

2). Terdapat kecenderungan mahasiswa pada pengetahuan tentang model Problem Based Learning masih sangat terbatas, karena mahasiswa masih menyamakan langkah-langkah pembelajaran dalam membuat RPP model Problem Based Learning dengan RPP yang lain, kesulitan pada pemilihan permasalahan kontekstual yang akan dipelajari, dan mengatur waktu pada langkah-langkah pembelajaran.Bagian ini memaparkan simpulan penelitian sesuai dengan hasil dan temuan penelitian. Bagian ini tidak perlu ada kutipan atas simpulan. Kesimpulan menggambarkan jawaban atas hipotesis dan / atau tujuan penelitian atau temuan ilmiah yang diperoleh. Kesimpulan tidak mengandung pengulangan hasil dan diskusi, melainkan merangkum temuan seperti yang diharapkan dalam tujuan atau hipotesis.

\section{REKOMENDASI}

Sesuai dengan hasil penelitian dapat memberikan sedikit sambungan berupa pemikiran guna meningkatkan kualitas calon guru dari program studi pendidikan matematka FKIP Universitas Mataram pada umumnya. Saran yang dapat penulis ajukan adalah sebagai berikut.

1). Mahasiswa sebelum membuat RPP model Problem Based Learning, sebaiknya mengacu pada komponen-komponen RPP yang sesuai dengan sintaks model Problem Based Learning, agar rumusan yang dibuat tidak melenceng dari esensi yang tertuang sesuai dengan kurikulum yang berlaku.

2). Mahasiswa sebaiknya mempelajari kembali tentang mata kuliah P3M, karena mata kuliah P3M adalah mata kuliah yang membahas tentang RPP.

3). Mahasiswa sebaiknya mempelajari kembali tentang evaluasi pembelajaran, terkait penilaian dan penggunaan instrumen penilaian karena hal tersebut sangat penting menjadi bekal sebelum menjadi guru yang sesungguhnya.

4). Sebagai mahasiswa khusus dari program studi pendidikan matematka FKIP Universitas Mataram yang akan mencetak menjadi seorang guru, dedikasi dalam profesi itu penting sehingga motivasi dalam menjalankan tugas harus terpatri dalam hati. Jadi teruslah memacu diri untuk menjadi guru yang baik dengan cara memperkaya diri dengan materi pelajaran, membiasakan diri tampil di depan umum, melengkapi dan mempersiapkan perangkat pembelajaran dengan sistematis dan terstruktur.Rekomendasi menggambarkan hal-hal yang akan 
dilakukan terkait dengan ide penelitian selanjutnya. Hambatan atau masalah yang dapat mempengaruhi hasil penelitian juga disajikan pada bagian ini.

\section{REFERENSI}

Arikunto, S. (2013). Dasar-dasar evaluasi pendidikan. Jakarta: PT. Bumi Aksara.

Izzati, N. (2017). Meningkatkan kemampuan mahasiswa dalam menyusun rpp melalui penerapan model pembelajaran berbasis portofolio (studi kuasi eksperimen terhadap mahasiswa tadris matematika IAIN Syekh Nurjati Cirebon). Euclid, 4(1): 604-688. Retrieved from: http://fkipunswagati.ac.id/ejournal/index.php/euclid/article/view/254/244.

Ngalimun. (2014). Strategi dan model pembelajaran. Aswaja pressindo. Yogyakarta.

Nurmahmidah. (2017). Penerapan model pembelajaran kooperatif tipe teams games tournament (TGT) pada pokok bahasan peluang sebagai upaya meningkatkan prestasi dan motivasi belajar matematika siswa kelas X MIA 2 SMA Negeri 1 Sedayu. Jurnal Mercubuana, 1(2): 139-146.

Putri, I. S., \& Agustyaningrum, N. (2017). Efektivitas model pembelajaran problem based instruction dan snowball throwing ditinjau dari hasil beljar matematika siswa kelas VIII SMPN 51 Batam. Jurnal Mercubuana, 1(2): 97-103.

Widoyoko, S, E, P. (2009). Belajar dan faktor-faktor yang mempengaruhinya. Jakarta: Rineka Cipta.

Winkel, W. S. (2004). Psikologi pengajaran. Yogyakarta: Media Abadi. 